\title{
ICT and the Teaching of Reading Comprehension in English as a Second Language in Secondary Schools: Problems and Prospects
}

\author{
Chinyere Henrietta Maduabuchi (Corresponding author) \\ Dept. of Arts and Social Science Education, Faculty of Education, \\ Ebonyi State University, Abakaliki, Ebonyi State, Nigeria \\ E-mail: ettachimlo@yahoo.com \\ Emechebe Vivian I \\ Dept. of Arts and Social Science Education,Faculty of Education, \\ Ebonyi State University, Abakaliki, Ebonyi State Nigeria
}

Received: 17-05- 2016

doi:10.7575/aiac.ijels.v.4n.3p.18
Accepted: $30-06-2016$

URL: http://dx.doi.org/10.7575/aiac.ijels.v.4n.3p.18
Published: 31-07-2016

\begin{abstract}
This study is aimed at identifying both prospects and problems of using Information and Communication Technology (ICT) in teaching reading comprehension in English as Second Language. To achieve this aim, a total of 25 secondary school English teachers were interviewed through the use of questionnaire. The teachers were purposively and pragmatically selected from 5 private schools and 4 public schools in the Abakaliki metropolis of Ebonyi State of Nigeriato ensure that both private and public schools were represented in the sample. The results of descriptive statistical analyses revealed that the most important prospects of using ICT in teaching reading comprehension included: the obvious improvement in vocabulary building and usage through the use of online dictionary; as well as the excitement about reading comprehension lessons often expressed by the students, which facilitated students' learning process and promotion of meaningful learning among others. However, there were problems that were very prevalent with the use of ICT in the classrooms. These were: difficulty in classroom control, distractions caused by irrelevant websites, poor maintenance, and lack of infrastructure. The findings of the study are expected to provide the teachers and policy makers with a better and more accurate picture of problems and prospects of integrating ICT in the teaching of reading comprehension in English as a Second Language classrooms.
\end{abstract}

Keywords: Information and communication technology, Reading comprehension, Problems, Prospect, English as a second language

\section{Introduction}

In the last decades, there has been an increasing call for the integration of Information and Communication Technology (ICT) into teaching and learning. ICT covers a wide range of technologies. It refers to all technological tools and resources used for communication, creation, dissemination, storage, management, and retrieval of information (Nordin, Embi \& Yunus, 2010; Thierer, 2001). These technologies include computers, mobile phones, television, radio, internet and so on.

According to Wernet, Olliges and Delicatch (2000), ICT empowers education as it is seen as media that offer learners a wide range of information, which the teacher may not have control over. In other words, the learner does not necessarily need to be in the classroom as learning can occur anywhere with the use of these technologies. These technologies also offer the learner the opportunity to control their learning process. ICT is a valuable tool to enhance teaching and learning. For teachers, ICT is a professional resource, a mode of classroom delivery, and a source of valid and valuable text types (Nordin et al., 2010). For students, ICT provides opportunities to communicate more effectively and to develop literacy skills including skills in critical literacy. It is a valuable tool for researching, composition and despondence (Nordin et al., 2010).

ICT also plays an important role in helping learners find reading materials from original sources. In finding articles from international journals, students can get it just by sitting in front of computers connected to the internet network. ICT facilitates teaching and learning process by providing access to wider sources of information and varieties of articles. With ICT in education, learner centered-approach is encouraged as the students can access and learn from these technologies at their pace, thereby developing learner's autonomy (Maduabuchi, 2007).

Reading, on the other hand, is the basis for learning different subjects. Whatever aspect of life one is considering, one discovers that the ability to read efficiently enhances individual's ability to function in an effective manner. It is one of the skills in English as a second language. Maduabuchi (2007) postulates that reading is an interaction between the reader and the text which results in comprehension. Reading is a receptive language process. In reading, there is an interaction 
between language and thought as the writer encodes thought as language and the reader decodes language as thought. In view of this, Nwaiwu (2007) opined that reading is a form of communication in which the decoder (reader) endeavors to interpret the mind of the encoder (writer). Through reading, the reader sees, hears, and converses with the writer who may or may not be familiar to him/her. Reading is a multifaceted process that develops only with practice. There are certain aspects of reading, such as fluency and word recognition, which can be learned with time. These basics must be mastered but at the same time reading comprehension should be emphasized in the process.

Reading plays a major role in making one a functional individual in the society. Some benefits of reading include: mental stimulation, stress reduction, knowledge increase, vocabulary expansion, entertainment, and improvement in one's analytical thinking skills among others. However, there are some factors which may impede reading. These factors include environmental, physiological, and psychological factors.

The use of ICT in the teaching and learning of English as a second language is one of the most widely discussed issues in the field of education (Yunus \& Salehi, 2012). Several ICT researchers have claimed that the usage of ICT in teaching and learning improves education and provides more teaching and learning supports for the teachers and learners (Salehi \& Salehi, 2012; Yunus, Salehi \& Chenzi, 2012; Young, 2003). There is no doubt that effective use of ICT in education improves teachers' instructional process and facilitates students' learning process. Several factors have been identified to be affecting the integration of ICT in the teaching of reading in secondary school. Boakye and Banin (2008) identified factors such as teacher-level, school-level and system-level. Teachers' integration of ICT into teaching could also be influenced by organizational factors and attitude towards technology (Chen, 2008). Poor infrastructure, limited school budget and poor maintenance culture have also been identified as barriers to proper ICT integration into teaching in most Nigerian secondary school (Adomi \& Kpangban, 2010).

In another study by Aduwa-Ogiegbran and Iyamu (2005), they examined the major obstacles militating against the use of ICT in secondary education in Nigeria. The major stumbling block to the adoption of ICT in secondary education in Nigeria were identified to be the high cost of computer hardware and software, weak infrastructure, lack of human skills and knowledge in ICT, and lack of relevant software appropriate and culturally suitable to Nigeria. These factors seem to have constituted enough stumbling blocks to the use of ICT in the teaching of reading comprehension in an ESL classroom at the secondary school level in Abakaliki metropolis, hence the justification for this survey.

\subsection{Theoretical Framework}

Since Siemens' (2008) Connectivism: Learning as Network creation and Downes' (2005) An introduction to connective knowledge, an extended discourse has ensued in and around the status of connectivism as a learning theory for the digital age. Kerr (2007) identifies two purpose for the development of a new theory. It replaces older theories that have become less frequent inferior, and the new theory builds on older ones without discarding them. Forster (2007) maintains that for connectivism to be a learning theory, the theory's limitations and the full range of contexts in which learning can take place must be accounted for. Otherwise, connectivism implementation by teachers may be insufficient and misguided.

With the changes that have occurred as a result of increased accessibility to information and a rapidly evolving technological ideas educators in higher learning institutions have been forced to adapt their teaching approaches without a clear roadmap for attending to students' various needs. The wide range of approaches and learning paths that are available to redesign curricula cause friction for educators and instructional designers who are required to deliver course materials in accordance with learning outcomes prescribed and mandated by educational institutions.

Connectivism is a theoretical framework for understanding learning. In connectivism, the starting point for learning occurs when knowledge is actuated through the process of a learner connecting to and feeding information into a learning community (Siemens, 2008). He states that a community is a cluster of similar areas of interest that allows for interaction, sharing, dialoguing and togetherness. In the connectivism model, a learning community is described as a node, which is always part of a larger network. Nodes arise out of the connection points that are found on a network. A network is comprised of two or more nodes linked together in order to share resources. Nodes may be of varying size and strength, depending on the concentration of information and the number individuals who are navigating through a particular node (Downes, 2008).

According to connectivism, knowledge is distributed across an information network and can be stored in a variety of digital formats. Learning and knowledge are said to rest in diversity of opinions (Siemens, 2008). Learning transpires through the use of both the cognitive and the affective domains; cognition and emotions both contribute to the learning process in important ways. Since information is constantly charging, its validity and accuracy may change over time, depending on the discovery of new contributions pertaining to a subject. By extension, one's understanding of a subject, one's ability to learn about the subject in question will also change over time. Connectivism stresses that two important skills that contribute to learning are the ability to seek out current information. That is to say, the capacity to know is more critical than what is actually known. The ability to make decisions on the basis of information that has been acquired is considered integral to the learning process.

The learning process is cyclical, in that learners will connect to a network to share and find new information, will modify their beliefs on the basis of new learning, and will then connect to a network to share these realizations and find new information once more. Learners may transverse networks through multiple knowledge domains. The peripheries of 
knowledge fields are porous, allowing for the interdisciplinary connections to be made. Siemens (2008) asserts, that the ability to see connections between fields, ideas and concepts is a core skill. The connectives metaphor is particularly timely, since the navigation of the internet and the means by which information is dispersed on the internet now provides a reference point for Siemens' assertion.

Connectivism has several considerable implication to education and research, as follows:

- Connectivism promotes the acquisition of the most relevant and factual information through accessing multiple "network". It also recognizes that the ability to sort and prioritize the tremendous amount of online information according to its accuracy and relevancy is a difficult skill to master. To help facilitate this process, educators and students must access various online tools. For website evaluation, the ability to access the newest information alters the foundations for future study (Siemens, 2008).

- It helps in learning to connect with information, rather than rote memorization of basic facts.

- The learner connects to information that is available within a network, then builds upon this information to form new knowledge, then shares it back into the network for others to access.

- It models and provides instruction on accessing and sharing of information within multiple networks.

- It allows students to use multiple technological devices that are able to connect to the internet.

- It creates connections with other students, classes, or schools to facilitate the sharing of information through network.

- It continually instructs students in the critical evaluation of web based content.

\subsection{Objective}

Due to an incessant call for the integration of ICT into teaching and learning in recent time, the researchers therefore, deem it fit to find out the problems and prospects of using ICT in the teaching of reading comprehension in English as a Second Language in secondary schools in Abakaliki metropolis of Ebonyi State.

\subsection{Research Questions}

1. What are the prospects of ICT on the teaching of reading comprehension in secondary schools in Abakaliki metropolis of Ebonyi State?

2. What are the problems of using ICT in the teaching of reading comprehension secondary school in Abakaliki metropolis of Ebonyi State?

\section{Methodology}

The design of the study is a descriptive survey research aimed at finding the problems and the prospect of using ICT in the teaching of reading comprehension in secondary schools.

The population for the study consisted of English teachers in nine selected secondary schools. Among the nine selected schools five were private schools while four were public schools. A total of 25 teachers were studied, 10 from the private schools and15 from the public schools. A random sampling technique was employed in selecting these schools. The purpose of using both private and public schools was for them to be represented in the sample. Data for the study were collected through a structured questionnaire developed by the researchers (Appendix A). The questionnaire contained 11 questions. Four questions were meant to examine the prospects, whereas seven questions were used to examine the problems of using ICT in the teaching of reading in the secondary schools. Twenty-five copies of the questionnaire were distributed and then collected on the spot to ensure maximum return through the help of the research assistants trained for this purpose. Two research assistants were trained in the administration and collection of the instrument.

\section{Results}

In the course of the investigation, the following results were discovered. The first research question addressed the prospects of using ICT on the teaching of reading comprehension in secondary schools in Abakaliki metropolis of Ebonyi State. Table 1 shows the frequency of positive and negative responses given by the teachers:

Table 1. Prospects of Using ICT $(\mathrm{N}=25)$

\begin{tabular}{clcc}
\hline \multicolumn{1}{c}{ Items } & Yes & No \\
\hline 1. Does your school have ICT gadgets? & 15 & 10 \\
2. Can ICT help to improve reading comprehension in students? & 22 & 3 \\
3. Do ICT tools make reading comprehension class interesting? & 17 & 8 \\
4. Are you computer literate? & 15 & 10 \\
\hline
\end{tabular}

The second research question addressed the problems of using ICT on the teaching of reading comprehension in secondary schools in Abakaliki metropolis of Ebonyi State. Table 2 shows the frequency of positive and negative responses given by the teachers: 


\begin{tabular}{clcc}
\hline \multicolumn{1}{c}{ Items } & Yes & No \\
\hline 5. & Are ICT facilities accessible? & 12 & 13 \\
6. Have you ever thought any topic of reading comprehension with the ICT gadgets? & 5 & 20 \\
7. Are those ICT gadgets functional? & 10 & 15 \\
8. $\begin{array}{l}\text { Do the students actually access the websites you instructed them to access when } \\
\text { allowed to read up an article on the internet? }\end{array}$ & 10 & 15 \\
9. Do you lose control of the classroom once they are in the computer laboratory? & 17 & 8 \\
10. Do you think that the students are usually distracted when they are having a lesson \\
$\begin{array}{l}\text { on reading comprehension in the computer laboratory? } \\
\text { 11. Are there disadvantages of using ICT in the teaching of reading comprehension in } \\
\text { secondary schools? }\end{array}$ & 18 & 7 \\
\hline
\end{tabular}

As it is evident from the results of the current study, most ESL teachers have never attempted to use ICT tools in the teaching of reading comprehension despite being computer literate. Another remarkable result is that although ICT gadgets are very important in the teaching of reading comprehension, the disadvantages also abound. We also found that most secondary schools have ICT gadgets, but these gadgets are accessible and functional in some schools which are mostly private schools. Our findings also indicated that most teachers who preferred conventional methods were not computer literate.

\section{Discussion}

The result of this study indicates that most secondary schools especially the private schools are equipped with ICT gadgets. Although some government owned schools have ICT gadgets, they are not functional and accessible for teachers and students. Again, most teachers of English prefer the conventional method of teaching, so they never attempt to use ICT tools in the teaching of reading.

The prospects may include, the chances of helping the students to improve vocabulary building and use. Also, the students may be fascinated and enthusiastic about having lessons on reading comprehension when ICT tools are used. More so, these ICT tools may facilitate students learning process and promote meaningful learning as online dictionary is handy to help the students with meaning of words, their synonyms and antonyms as well. These findings are in accordance with findings of (Yuksel \& Anriverdi, 2009; Horton \& Moorman, 2009).

Findings on the problems of ICT in the teaching of reading comprehension in secondary schools include the possibility of students being distracted by other websites apart from the one they are instructed to visit. There is also the tendency of losing control of the classroom as most of the students may be carried away and so pay little or no attention to what the teacher is saying.

\section{Conclusion}

There were four prospects of ICT in the teaching of reading comprehension as reported by the teachers. First, the use of ICT was said to be beneficial in terms of attracting students' attention. Secondly, with ICT gadgets, suitable online reading materials are made available to the students. Again, it could help students improve their vocabulary and enable them to find out the meaning of words in the texts they read. Lastly, ICT usage could meet the teachers teaching objectives as ICT aids the teaching process. With regards to the problems of ICT in the teaching of reading comprehension, it is reported that teachers found it more difficult to control the class once a lesson is going on with ICT tools. Students became too excited when ICT was used and this caused problems to teachers in terms of class control. Besides that, students might be distracted by other elements in the website when they use internet. Apart from the distraction factor, teachers were afraid of the actual content from students' reading on the internet as there were so many articles available and students might not actually read what they are required to.

\section{Recommendation}

Considering the importance and presence of high technological appliances in education, educational stakeholders have the responsibilities of not merely providing computers for schools, but also to raise a culture of acceptance amongst the end users. They should also endeavor to make the ICT tools functional and accessible.

Also, teachers' workload in schools should be reduced so as to give them time to prepare for their lessons, as a lot of time is needed to plan and construct lesson using ICT. Teachers of English should also be encouraged to employ the use of ICT in the teaching especially when teaching reading comprehension as its prospects are enormous but bearing in mind the problems which abound in order to curtail them and maximize its potentials.

In order to solve the problems that may arise when ICT is integrated in the teaching of reading comprehension in an ESL classroom, it is important for teachers to employ strict supervision of the students especially when they are asked to access a website independently. Finally, the teacher may have to group the students into smaller numbers to enable him/her control them while the lesson is going on. 


\section{References}

Abanikannda M. Oluwafemi (2011). Integrating information and communication technology (ICT) into teacher education. Ibadan: Stirling- Horden Publishers Ltd,

Adomi, E. E., \& Kpangban, E. (2010). Application of ICTs in Nigerian secondary schools. Library Philosophy and Practice (e-journal), 345.

Aduwa-Ogiegbean, S. E. \& Iyamu, E.O.S. (2005). Using ICT in secondary schools in Nigeria Educational Technology \& Society 8(1) 104-112.

Boakye, K. B. \& Banini, D. A. (2008). Teacher ICT readiness in Ghana. In K. Toure, T.M.S.

Chen, C.H (2008). Why do teachers not practice what they believe regarding technology integration? Journal of Educational Research, 102, (1) $65-75$

Considine, D; Horton, J \&Moormen, G (2009) Teaching and reading the millennial generation through media literacy. Journal of Adolescent and Adult literacy, 52 (6) $471-481$

Downes, S, (2005). An Introduction to connective knowledge. Stephen's web Retrieved from http://www.downes.Ca/cgibin/page.cgi?Post $=33034$.

Kerr, B. (2007, February 3). Msg. 7, Re: What connectivism is. Online connectivism conference: University of Manitoba. http://Itc.Umantoba.ca/Moodle/mod/forum/discuss.php?d=12

Maduabuchi, C. (2007). Challenges of teaching reading for functional literacy via ICTs. Journal of Applied Literacy and Reading 13, $159-166$.

Nordin, N., Embi, M. A., \& Yunus, M. M. (2010). Mobile learning framework for lifelong learning. Procedia-Social and Behavioral Sciences, 7, 130-138.

Salehi, H., \& Salehi Z., (2012). Integration of ICT in a language teaching: Challenges and barriers. Proceedings of the $3^{\text {rd }}$ International Conference on e-Education, e-Business, e-Management and e-Learning (IC4E, 2012). IPEDR, 27. 2015 -219 .

Siemens, G. (2008). About: Description of connectivism: A learning theory for today's learner, website. http://www.connectivism.Ca/about.html.

Thierer, A.D: (2001). How free computers are filling the "digital divide". Washington DC; Heritage Foundation.

Wernet, S. P., Olliges, R. H., \& Delicath, T. A. (2000). Post course evaluation of web ct (web course tools) classes by social work students. Research on Social Work Practice, 10(4), $\quad$ 487-504.Retrieved August 10, 2014 from http://www.ifets.info/journals/13_1/16.pdf.

Young, S.S.C (2003). Integrating ICT into second language education in a vocational high school. Journal of Computers Assisted Learning, 19, 447 - 461. http://dx.doi.org/10.1046

Yuksel, D., \& Tanriverdi, B. (2009). Effects of watching captioned movie clip on vocabulary development of EFL learners. The Turkish Online Journal of Educational Technology, 8(2)33-47

Yunus, M. M., \& Salehi, H. (2012). The effectiveness of Facebook groups on teaching and improving writing: Students' perceptions. Journal of Education and Information Technologies, 1(6), 87-96.

Yunus, M. M., Salehi, H. \& Chenzi, C. (2012). Integrating social networking tools into ESL \& writing classroom; strengths and weakness. English Language Teaching, 5(8)42-48 http://dx.doi.org/10.5539/elt.v5n8p42. 
Appendix A. Prospects and Problems of Using ICT Questionnaire

\begin{tabular}{|c|c|c|}
\hline Items & Yes & No \\
\hline 1. Does your school have ICT gadgets? & & \\
\hline 2. Can ICT help to improve reading comprehension in students? & & \\
\hline 3. Do ICT tools make reading comprehension class interesting? & & \\
\hline 4. Are you computer literate? & & \\
\hline 5. Are ICT facilities accessible? & & \\
\hline $\begin{array}{l}\text { 6. Have you ever thought any topic of reading comprehension with } \\
\text { the ICT gadgets? }\end{array}$ & & \\
\hline 7. Are those ICT gadgets functional? & & \\
\hline $\begin{array}{l}\text { 8. Do the students actually access the websites you instructed them } \\
\text { to access when allowed to read up an article on the internet? }\end{array}$ & & \\
\hline $\begin{array}{l}\text { 9. Do you lose control of the classroom once they are in the } \\
\text { computer laboratory? }\end{array}$ & & \\
\hline $\begin{array}{l}\text { 10. Do you think that the students are usually distracted when they } \\
\text { are having a lesson on reading comprehension in the computer } \\
\text { laboratory? }\end{array}$ & & \\
\hline $\begin{array}{l}\text { 11. Are there disadvantages of using ICT in the teaching of reading } \\
\text { comprehension in secondary schools? }\end{array}$ & & \\
\hline
\end{tabular}

